\title{
Penggunaan Metode Pembelajaran Modelling Mata Pelajaran Matematika Materi Keliing Dan Luas Bangun Persegi dan persegi panjang Kelas III Pada MI AI Bashor Lamongan
}

\author{
Nilna Iqbal Dzakiyyyah \\ Fakultas Agama Islam Universitas Islam Darul ‘Ulum Lamongan \\ Jl. Airlangga No. 03 Sukodadi Lamongan \\ Email: nielnozakiyah@gmail.com
}

\begin{abstract}
This study aims to determine an increase in student learning outcomes after applying modeling methods in mathematics subject matter around and square area in MI Al Bashor Lamongan. With the modeling method it is expected to encourage students to increase their interest in learning. The study design used the PTK method with results in the first cycle learning completeness $72 \%$ with an average value of students 74 . In the second cycle completeness reached $81 \%$ with an average score of 77 students. Judging from the results of the research it seems that the adoption of modeling methods can improve learning outcomes mathematics material around a square in MI Al bashor lamongan
\end{abstract}

Keyword: learning outcomes, mathematics, modeling methods

\begin{abstract}
Abstrak
Penelitian ini bertujuan untuk mengetahui adanya peningkatan hasil belajar siswa setelah diterapkan metode modeling pada mata pelajaran matematika materi keliling dan luas persegi di MI Al bashor lamongan. Dengan metode modelling diharapkan dapat mendorong siswa meninggkatkan minat belajar. Desain penelitian menggunakan metode PTK dengan hasil pada siklus I ketuntasan belajar 72\% dengan nilai rata-rata siswa 74 . Pada siklus ke II ketuntasan mencapai $81 \%$ dengan nilai rata-rata siswa 77 . Dilihat dari
\end{abstract}


hasil penelitian terlihat epenerapan metode modeling dapat menningkatkan hasil belajar matematika materi keliling bangun persegi dan persegi panjang di MI Al bashor lamongan

Kata kunci: Hasil Belajar, Matematika, Modelling

\section{A. Pendahuluan}

Pendidik merupakan tolak ukur pertama yang akan di gugu dan ditiru oleh seorang peserta didik. Oleh karena itu seorang pendidik harus mempunyai kualitas dalam proses pembelajaran, guru memerlukan wawasan yang mantap dan utuh tentang kegiatan belajar mengajar. Seorang pendidik harus mengetahui dan memiliki gambaran secara menyeluruh mengenai bagaimana proses belajar mengajar itu terjadi serta langkah - langkah apa yang diperlukan sehingga tugas - tugas guru bisa dilakukan dengan baik dan memperoleh hasil sesuai dengan tujuan yang diharapkan.

Pendidikan sebagai lembaga dan usaha pembangunan bangsa. Pendidikan mencakup ruang lingkup yang amat luas, yaitu pendidikan kemampuan mental, pikir dan kepribadian manusia seutuhnya. Guru yang baik adalah guru yang berhasil dalam pengajaran, dan mampu memberikan konsep seseuai dengan tujuan pembelajaran yang akan disammpaikan. Pendukung utama tercapainya tujuan pengajaran juga adalah suasana kelas yang baik dalam arti seluas - luasnya. Karena itu segala macam tindakan pembinaan pendidikan sepatutnya diarahkan pada kelas. Dalam kelas lah segala aspek pengajaran bertemu dan berproses. Guru dengan segala kemampuannya, siswa dengan segala latar belakang dan sifat individunya, kurikulum dengan segala komponennya, materi, sumber pelajaran dengan segala aspek pokok bahasannya, metode beserta model pembelajaran yang dilakukan berpadu berinteraksi di kelas. Bahkan hasil dari pendidikan dan pengajaran sangat ditentukan oleh apa yang terjadi di kelas. Oleh karena itu peran seorang pendidik sngatlah penting.

Matematika merupakan salah satu bidang studi yang diajarkan di SD/MI. "Belajar matematika adalah belajar konsep dimulai dari benda-benda real kongkrit secara intutif, kemudian pada tahap-tahap yang lebih tinggi konsep itu diajarkan lagi 
dalam bentuk yang lebih abstrak dengan mengunakan notasi yang lebih umum dipakai dalam matematika". ${ }^{1}$ Selama ini pelajaran matematika merupakan mata pelajaran yang menjadi momok dan beban bagi siswa apalagi dengan cara mengajar yang kurang menarik dan minimnya penggunaan alat peraga, maka hal ini yang membuat minat belajar matematika. Metode modelling merupakan belajar melalui obeservasi dengan menambahkan atau mengurangi tingkah laku yang teramati, menggenalisir berbagai pengalaman sekaligus, melibatkan proses kognitif. ${ }^{2}$

Pembelajaran menggunakan metode modelling diharapkan dapat mendorong siswa dalam meningkatkan hasil belajar, hal ini dikarenakan hasil nilai dari pelajaran matematika siswa kelas III MI Al bashor lamongan masih kurang dan banyak yang belum memenuhi KKM yang telah ditetapkan. Maka dari itu diharapkan proses pembelajaran pelajaran matematika dengan metode modeling dapat membantu nilai dan prestasi belajar siswa.

Berdasarkan uraian di atas maka dalam penelitian ini penulis menggunakan metode modeling sebagai salah satu cara memcahkan permasalahan yang ada di kelas, terutama dalam mata pelajaran matematika. Dengan metode tersebut diharapkan mampu membawa siswa belajar dalam suasana yang lebih nyaman dan menyenangkan. Dengan menetapkan judul "Penggunaan Metode Pembelajaran Modelling Mata Pelajaran Matematika Materi Keliing Dan Luas Bangun Persegi dan persegi panjang Kelas III Pada MI Al Bashor Lamongan’’.

\section{B. Kajian Teori}

Teori modeling dikembangkan berdasarkan teori observational yang mengatakan bahwa belajar dapat diperoleh secara langsung maupun tidak langsung melalui pengamatan tingkah laku orang lain berikut konsekuensi - konsekuensinya.

\footnotetext{
${ }^{1}$ Ruseffendi, E.T. Penilaian Pendidikan dan Hasil Belajar Siswa Khususnya dalam Pengajaran Matematika untuk Guru dan Calon Guru. Bandung: Tarsito. (1991).

2 Komalasari, Gantina dkk. 2011. Teori dan Teknik Konseling. Jakarta: Permata Puri Media.2011: 176
} 
Perilaku tersebut dipengaruhi oleh interaksi stimulus, respon, penguat eksternal, dan proses mediasi kognitif individu "Modeling atau biasa disebut dengan Imitasi adalah peniruan (pengkopian) perilaku, yaitu meniru perilaku seseorang, dimana perilaku orang yang ditiru tersebut merupakan suatu pola." 4 strategi modeling adalah suatu strategi dalam konseling yang menggunakan proses belajar melalui pengamatan terhadap model dan perubahan perilaku yang terjadi karena peniruan. ${ }^{5}$ Modeling merupakan belajar melalui obeservasi dengan menambahkan atau mengurangi tingkah laku yang teramati, menggenalisis berbagai pengalaman sekaligus, dan kemudian melibatkan proses kognitif. ${ }^{6}$

Kesimpulan dari beberapa ahli di atas meyatakan bahwa metode modeling merupakan pembelajaran yang diaplikasikan dengan cara mengamati atau meniru tingkah laku yang melibatkann proses kogntif. beberapa hal yang perlu diperhatikan dalam pembelajaran dengan pengamatan terhadap metode modelling, ${ }^{7}$ yaitu sebagai berikut:

1) Memberikan Perhatian (Attention)

Sebagai pengamat, orang tidak dapat belajar melalui observasi kecuali kalau memerhatikan kegiatan-kegiatan yang diperagakan oleh model itu dan benar-benar memahaminya. Ini tergantung seberapa sederhana dan mencolok mata perilaku yang diperagakan itu. Perilaku yang lebih sederhana dan lebih mencolok mata lebih mudah diperhatikan dari pada yang tidak jelas.

${ }^{3}$ Rahmawati, Hetti. Modifikasi Perilaku Manusia. Malang: Fakultas Ilmu Pendidikan Universitas Negeri Malang. (2009: 91)

${ }^{4}$ Uno, Hamzah B. Orientasi Dalam Psikologi Pembelajaran. Jakarta: PT. Bumi Aksara. (2012: 194)

${ }^{5}$ Nursalim, Mochamad. Strategi dan Intervensi Konseling. Jakarta: Akademia Permata. (2013: 121)

${ }^{6}$ Komalasari, Gantina dkk. Teori dan Teknik Konseling. Jakarta: Permata Puri Media (2011: 176)

${ }^{7}$ Uno, Hamzah B. Orientasi Dalam Psikologi Pembelajaran. Jakarta: PT. Bumi Aksara. (2012: 196) 
2) Model yang Menarik (Attractive Model)

Seperti yang biasa kita lihat, pariwara (iklan) di media cetak atau televisi dapat menarik banyak perhatian. Media televisi umumnya merupakan sarana menarik perhatian (attractive getting devide) yang sangat efektif untuk tujuan modeling perilaku.

3) Menyimpan dalam Ingatan (Retention)

Setelah perilaku diamati, seorang pengingat diharapkan dapat mengingat apa yang telah dilihatnya. Hal ini bisa dilakukan dengan point penting atau catatan dari informasi yang telah didapatkan menjadi bentuk gambar mental (mental picture) atau menjadi simbol-simbol verbal yang kemudian disimpan dalam ingatannya. Akan sangat membantu apabila kegiatan yang akan ditiru segera diulang dan dipraktikan setelah pengamatan selesai.

4) Proses Produksi (Production)

Setelah melalui tahap-tahap peniruan, pengamatan dapat mengubah ide gambar yang di dalam ingatannya menjadi suatu tindakan. Tindakan tersebut dapat direkam melalui video sebagai alat bantu. Hal ini merupakan salah satu cara pemberian umpan balik bagi si pengamat sebagai observasi diri (self observation) melalui penayangan kembali rekaman video.

langkah-langkah modeling adalah sebagai berikut ${ }^{8}$ :

1) Menetapkan bentuk penokohan (live model, symbolic model, multiple model).

2) Pada live model, pilih model yang sebaya atau saudara yang memiliki kesamaan seperti; usia, status ekonomi, dan penampilan fisik. Hal ini penting terutama bagi anak-anak.

3) Bila mungkin gunakan lebih dari satu model.

${ }^{8}$ Komalasari, Gantina dkk. Teori dan Teknik Konseling. Jakarta: Permata Puri Media (2011: 179) 
4) Kompleksitas perilaku yang dimodelkan harus sesuai dengan tingkat perilaku konseli.

5) Kombinasikan modeling dengan aturan, intruksi, behavioral rehearsal, dan penguatan.

6) Pada saat konseli memperhatikan penampilan tokoh berikan penguatan alamiah.

7) Bila mungkin buat desain pelatihan untuk konseli meniru model secara tepat, sehingga akan mengarahkan konseli pada penguatan alamiah untuk setiap peniruan tingkah laku yang tepat.

8) Bila perilaku bersikap kompleks, maka episode modeling dilakukan mulai dari yang paling mudah ke yang lebih sukar.

9) Skenario modeling harus dibuat realistik.

10) Melakukan pemodelan dimana tokoh menunjukan perilaku yang menimbulkan rasa takut bagi konseli (dengan sikap manis, perhatian, bahasa yang lembut dan perilaku yang menyenangkan konseli).

Pembelajaran matematika yang diajarkan di tingkat sekolah dasar merupakan mata pelajaran yang terdiri dari bagian-bagian matematika yang dipilih guna menumbuh kembangkan kemampuan-kemampuan dan membentuk pribadi anak serta berpedoman kepada perkembangan Ilmu Pengetahuan dan Teknologi. Hal ini menunjukkan bahwa mata pelajaran matematika SD memiliki ciri-ciri yang dimiliki matematika, yaitu: (1) memiliki objek kajian yang abstrak (2) memiliki pola pikir deduktif.

Pelajaran Matematika sebagai objek abstrak tentu saja sangat sulit untuk dapat dipahami oleh peserta didik SD yang belum mampu berpikir formal, sebab orientasinya masih terkait dengan benda-benda konkret. Ini tidak berarti bahwa matematika tidak mungkin tidak diajarkan di jenjang pendidikan dasar, bahkan pada 
hakekatnya matematika lebih baik diajarkan pada usia dini. ${ }^{9}$ Mengingat pentingnya matematika untuk siswa di SD, perlu dicari suatu cara mengelola proses pembelajaran pada tingkat sekoah dasar sehingga matematika dapat dicerna oleh peserta didik.

Disamping itu, dari pengertian diatas bahwa pelajaran matematika harus bermanfaat dan relevan dengan kehidupannya, pembelajaran yang diajarkan lebih kepada perilaku sehari-hari, seperti jual beli, menghitung keliling atau luas persegi contohnya pada salah satu benda yang ada disekitar. karena itu pembelajaran matematika di jenjang pendidikan dasar harus ditekankan pada penguasaan keterampilan dasar dari matematika itu sendiri.

Suatu proses pastinya bertujuan untuk mencapai sebuah hasil. Begitupun dengan proses belajar. Adanya suatu proses dalam belajar akan mencapai suatu hasil belajar. Harapannya adalah peserta didik mampu mendapatkan sebuah hasil belajar yang optimal. hasil belajar merupakan hasil dari suatu interaksi tindak belajar dan tindak mengajar. ${ }^{10}$ Selain itu terdapat penjelasan lain menerangkan bahwa hasil belajar adalah kemampuan- kemampuan yang dimiliki siswa setelah menerima pengalaman belajarnya. ${ }^{11}$

Skema kemampuan yang didapat menunjukkan hasil belajar yaitu: ${ }^{12}$

a. Keterampilan kognitif berkaitan dengan kemampuan membuat keputusan memecahkan masalah dan berfikir logis.

b. Keterampilan psikomotor berkaitan dengan kemampuan tindakan fisik dan kegiatan perspektual.

9 Amir, A. Pembelajaran Matematika SD Dengan Menggunakan Media Manipulatif. Forum Paedagogik. VI. (2014: 77)

${ }^{10}$ Dimyati dan Mudjiono. Belajar Dan Pembelajaran. Jakarta: PT Rineka Cipta. (2009: 3)

${ }^{11}$ Nana Sudjana, dkk. Media Pengajaran. Bandung: Sinar Baru Algensindo.(2002: 22)

12 Anitah, S. Dkk. Strategi Pembelajaran di SD. Tangerang Selatan: Universitas Terbuka, (2018; 2.19) 
c. Keterampilan afektif berkaitan dengan kemampuan sosial kepemimpinan.

d. Keterampilan interaktif berkaitan dengan kemampuan sosial kepemimpinan.

Berdasarkan dari pengertian diatas dapat disimpulkan bahwa hasil belajar merupakan suatu hasil yang dicapai oleh individu berupa kemampuan-kemampuan tertentu setelah melalui proses belajar dalam jangka waktu tertentu dan hasil belajar menjadi tolok ukur keberhasilan dalam proses belajar mengajar.

\section{Metode Penelitian}

PTK model Kemmis dan Mc Taggart pada hakikatnya berupa perangkat perangkat atau untaian - untaian dengan satu perangkat terdiri dari empat tahap yaitu: perencanaan, tindakan, pengamatan, dan refleksi. Keempat tahap merupakan satu kesatuan dalam siklus. Tahapan siklusnya dapat dijelaskan dengan bagan berikut ini :

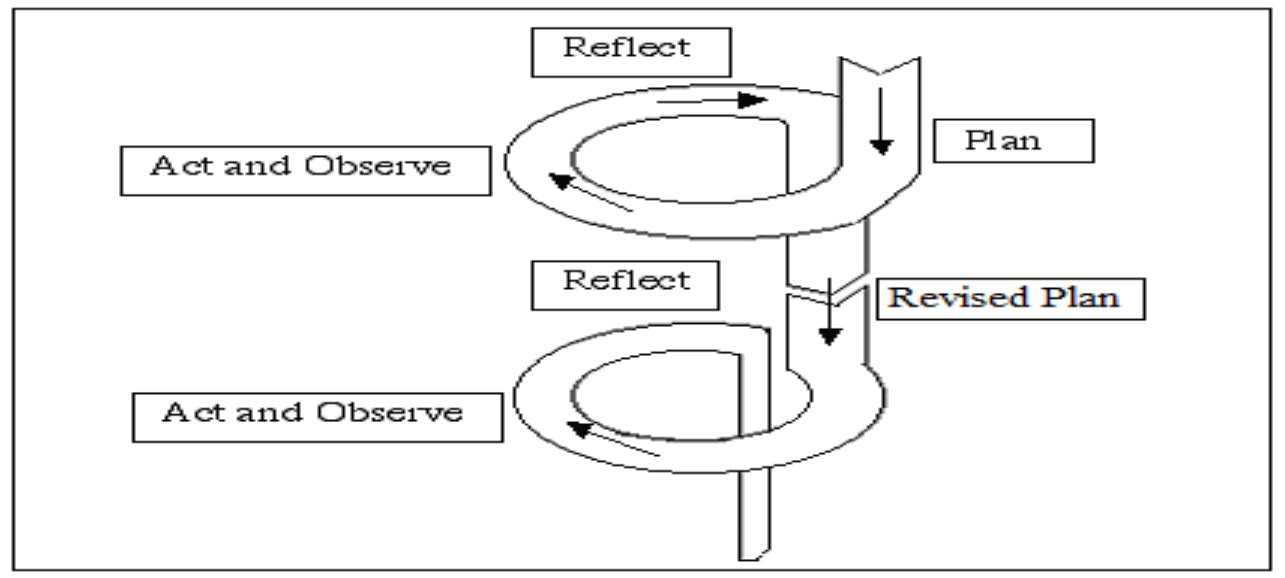

Gambar 3.1. Model Modifikasi oleh Kemmis dan Mc. Taggart (1991)

Model Kemmis dan Mc Taggart merupakan pengembangan dari konsep dasar yang diperkenalkan oleh Kurt Lewin, hanya perbedaanya pada tahap acting (tindakan) dengan observing (pengamatan) dijadikan sebagai satu kesatuan. Hal demikian disebabkan karena kedua tahap tersebut terdapat adanya kenyataan bahwa antara implementasi acting dan observing merupakan dua kegiatan yang tidak bisa 
dipisahkan. ${ }^{13}$ Hal ini didasari bahwa pada kenyataannya penerapan tindakan dan pengamatan tidak dapat dipisahkan. Dua kegiatan ini merupakan kegiatan yang dilakukan dalam waktu yang bersamaan. Keempat komponen dalam model Kemmis \& McTaggart dipandang sebagai suatu siklus, dalam hal ini merupakan suatu putaran kegiatan yang terdiri dari perencanaan, tindakan observasi dan refleksi. Berdasarkan refleksi kemudian disusun rencana (perbaikan), tindakan dan observasi serta refleksi, demikian seterusnya. Banyaknya siklus tergantung pada permasalahan yang akan dipecahkan.

Penjelasan alur prosedur Kemmis \& McTaggart di atas adalah:

1. Rancangan/rencana awal, sebelum mengadakan penelitian peneliti menyusun rumusan masalah, tujuan dan membuat rencana tindakan, termasuk di dalamnya instrumen penelitian dan perangkat pembelajaran.

2. Kegiatan dan pengamatan, meliputi tindakan yang dilakukan oleh peneliti sebagai upaya membangun pemahaman konsep siswa serta mengamati hasil atau dampak dari diterapkannya metode pembelajaran model Kelompok dengan pendamping siswa.

3. Refleksi, peneliti mengkaji, melihat dan mempertimbangkan hasil atau dampak dari tindakan yang dilakukan berdasarkan lembar pengamatan yang diisi oleh pengamat.

4. Rancangan/rencana yang direvisi, berdasarkan hasil refleksi dari pengamat membuat rancangan yang direvisi untuk dilaksanakan pada siklus berikutnya.

\section{Hasil Pembahasan}

Hasil penelitian diuraikan dalam bentuk tahapan yang terdiri dari siklus - siklus pembelajaran yang dilakukan dalam proses belajar di kelas. Proses pembelajaran pada siklus I seorang pendidik perlu adanya suatu tahapan yang sesuai dengan metode modelling, sehingga pendidik mampu mengetahui tingkat keberhasilan belajar pada

${ }^{13}$ Mu'alimin \& Cahyadi, R.A.H. Penelitian Tindakan Kelas Teori dan Praktik: Prinsip - Prinsip PTK hal (10-11). Pasuruan: Ganding Pustaka. (2014: 17). 
mata pelajar matematika. guru masih perlu berusaha menarik perhatian siswa dengan lebih baik karena suasana kelas masih gaduh akibat pembentukan kelompok. Siswa masih berusaha beradaptasi dengan anggota kelompok yang baru dibentuk, sehingga mereka tidak fokus pada pelajaran. Selain itu siswa belum terbiasa dengan kegiatan berdiskusi sehingga guru harus lebih berusaha membimbing kelompok agar bekerja lebih aktif dan efektif. Seorang pendidik harus memposisikan dirinya sebagai seorang fasilitator yang memunyai tugas untuk mengarahkan, memberikan penjelasan sehingga Penyampaian materi dan evaluasi sudah cukup baik.

Berdasarkan pengamatan pada siklus II, aktifitas siswa sudah mencapai indikator pencapaian aktifitas belajar yaitu mencapai nilai $81 \%$. Peningkatan aktifitas siswa ini disebabkan karena guru lebih aktif dalam mengorganisasikan kelompok dengan cara membimbing dan memandu siswa dalam kelompoknya serta penggunaan metode modeling mampu membuat siswa lebih aktif dan menarik minat siswa dalam pembelajaran. Siswa telah terbiasa dengan aktivitas kelompok sehingga membuat siswa lebih fokus dan tidak gaduh. Peneliti memberikan tes kepada siswa untuk mengetahui hasil belajar siswa pada mata pelajaran matematika tentang keliling dan luas bangun datar. Hasil tes belajar siswa pada pra siklus, siklus I dan siklus II dapat dilihat pada Tabel 4.18.

Tabel 4.18 Hasil Tes Siswa Pada Pra Siklus, Siklus I dan II

\begin{tabular}{|c|c|c|c|}
\hline $\begin{array}{c}\text { Pelaksanakan } \\
\text { Tindakan }\end{array}$ & Jumlah Skor & Rata-rata & $\begin{array}{c}\text { Persentase } \\
\text { ketuntasan }\end{array}$ \\
\hline Pra siklus & 750 & 68 & $54 \%$ \\
\hline Siklus I & 815 & 74 & $74 \%$ \\
\hline Siklus II & 855 & 77 & $81 \%$ \\
\hline
\end{tabular}

Berdasarkan pada Tabel 4.18 diatas, peneliti dapat mengetahui hasil belajar mengalami peningkatan. Pada pra siklus nilai rata-rata 68 dengan persentase ketuntasan 54\%. Pada pra siklus terdapat 5 siswa tidak mencapai KKM dari 11 siswa. Siklus I nilai rata-rata 74 dengan persentase ketuntasan 74\%. Pada siklus I ini 
terdapat 3 siswa yang tidak mencapai KKM dari 11 siswa. Sedangkan pada siklus kedua mendapatkan nilai yang rata-rata 77 dengan persentase ketuntasan $81 \%$ dan siswa yang tidak mencapai ketuntasan ada 2 siswa dari 11 siswa kelas III.

Teknik modeling dikembangkan berdasarkan teori observational yang mengatakan bahwa belajar dapat diperoleh secara langsung maupun tidak langsung melalui pengamatan tingkah laku orang lain berikut konsekuensi - konsekuensinya. ${ }^{14}$ Perilaku ini dipengaruhi oleh interaksi antar stimulus, respon penguat eksternal dan proses mediasi kognitif peserta didik. Sedangkan, pendapat lain menyatakan bahwa "Modeling atau Imitasi adalah peniruan (pengkopian) perilaku, yaitu meniru perilaku seseorang, dimana perilaku orang yang ditiru tersebut merupakan suatu pola."15 Lantas strategi modeling adalah suatu strategi dalam konseling yang menggunakan proses belajar melalui pengamatan terhadap model dan perubahan perilaku yang terjadi karena peniruan. ${ }^{16}$

Hal ini sesuai dengan penelitian yang dilakukan, bahwa dengan metode modeling peserta didik menjadi lebih mudah memahami materi yang disampaikan karena siswa dapat mengamati secara langsung benda - benda nyata bangun persegi dan persegi panjang yang di jadikan modeling. Peseta didik llebih mudah memahami dengan suuatu benda yang kongkrit sehingga menjadikan peserta didik lebih aktif bertanya tentang apa yang di peragakan oleh pendidik. Peserta didik dapat mengenal dan mengetahui bagian-bagian dari bangun persegi dan persegi panjang, dapat menemukan rumus keliling dan luas persegi dan persegi panjang dan dapat menghitung keliling dan luas persegi dan persegi panjang. Berdasarkan hasil dan pembahasan di atas, metode modeling yang diterapkan pada pembelajaran matematika dapat meningkatkan hasil belajar siswa kelas III dengan topik pembahasan menghitung keliling dan luas bangun persegi dan persegi panjang di MI Al Bashor Lamongan.

${ }^{14}$ Menurut Rahmawati, (2009: 91) berpendapat bahwa

${ }^{15}$ Uno (2012: 194)

${ }^{16}$ Menurut Bandura (dalam Nursalim 2013: 121), yang dimaksud 


\title{
E. Simpulan
}

\begin{abstract}
Peningkatan hasil belajar siswa dapat dilakukan oleh pendidik dengan menggunakan salah satu metode yakni metode modeling yang bertujuan untuk menarik minat siswa tentang materi pembelajaran mencari keliling dan luas bangun persegi dan persegi panjang di depan kelas dengan menggunakan media sederhana dan mudah ditemukan oleh siswa di sekitar kelas, pelaksanaan modeling siswa dibagi dalam beberapa kelompok agar siswa dapat berdiskusi untuk membuat kesimpulan dari pelaksanaan metode modeling ini. Sebelum pelaksanan modeling guru memperkenalkan alat dan bahan terlebih dahulu serta membimbing siswa agar mencatat hal-hal yang penting yang mereka lihat dari proses modeling, setelah pelaksanaan modeling selesai guru membimbing siswa untuk membuat kesimpulan di dalam kelompok agar semua siswa dapat mengeluarkan pendapatnya masing-masing kemudian siswa melaporkan hasil diskusi di depan kelas.
\end{abstract}

\section{DAFTAR PUSTAKA}

Amir, A. 2014. Pembelajaran Matematika SD Dengan Menggunakan Media Manipulatif. Forum Paedagogik. VI. Hal. 75

Anitah, S. Dkk. 2018. Strategi Pembelajaran di SD. Tangerang Selatan: Universitas Terbuka

Depdiknas. 2008. Kamus Besar Bahasa Indonesia. Indonesia: Gramedia Pustaka

Dimyati dan Mudjiono. (2002). Belajar Dan Pembelajaran. Jakarta: PT Rineka Cipta.

Komalasari, Gantina dkk. 2011. Teori dan Teknik Konseling. Jakarta: Permata Puri Media.

Mu'alimin \& Cahyadi, R.A.H. (2014). Penelitian Tindakan Kelas Teori dan Praktik: Prinsip - Prinsip PTK hal (10-11). Pasuruan: Ganding Pustaka.

Nana Sudjana, dkk. (2002). Media Pengajaran. Bandung: Sinar Baru Algensindo. 
Nursalim, Mochamad dan Suradi. 2002. Layanan Bimbingan dan Konseling. Surabaya: Unesa University Press.

Nursalim, Mochamad. 2013. Strategi dan Intervensi Konseling. Jakarta: Akademia Permata.

Ruseffendi, E.T. (1991). Penilaian Pendidikan dan Hasil Belajar Siswa Khususnya dalam Pengajaran Matematika untuk Guru dan Calon Guru. Bandung: Tarsito.

Sudjana, N dan Ibrahim. 1989. Penelitian dan Penilaian Pendidikan. Bandung: Sinar Baru.

Uno, Hamzah B. 2012. Orientasi Dalam Psikologi Pembelajaran. Jakarta: PT. Bumi Aksara. 